\title{
Semantic test of a technology management model in family business
}

\author{
Guillermo Jesús Larios Hernández ${ }^{1}$, Argentina Soto Maciel ${ }^{1 *}$
}

\begin{abstract}
This paper assembles family business conceptions from the innovation and technology management perspective, and tests them in the case of a Mexican sugarcane producer. Literature indicates that non-financial objectives, risk aversion and strong controls negatively influence family firms' innovation outcomes. Based on semantic network analysis, we collected transversal information on the firm's technology activities, innovation values and organizational flows, which allowed for the identification of an organizational management profile that shapes an innovation style. Although we acknowledge literature consistency in aspects such as family direct influence and control, or the importance of STI partnerships and external knowledge, our findings didn't identify any concerns about losing control in parts of the family business. This research contributes to the understanding of technology management and organizational elements in an emerging economy's family firm from a relational perspective. Implications for theory endorsement and characterization of family business innovation and technology management in developing countries are discussed.
\end{abstract}

Keywords: Family business; Management of technology; Innovation; Network analysis.

Submitted: June $21^{\text {st }} 2017 /$ Approved: September $28^{\text {th }} 2017$

\section{Introduction}

Innovation has long been considered essential for business growth (Aghion and Howit, 1992), especially in the context of globalization and hyper competition. A variety of organizational and strategic behaviors in family businesses have been identified, though our knowledge about the relation between family business behavior and innovation remains limited (De Massis, Frattini \& Lichtenthaler, 2013; Diéguez-Soto, Manzaneque \& Rojo-Ramírez, 2016). Continued research in this topic becomes therefore necessary, which improved understanding would help us identify determinants for family firm development. Family firms represents a significant share of total businesses worldwide, estimated between $65 \%$ and $90 \%$ of all companies (Durán and San Martín, 2016), which are obliged to face greater vulnerability as a consequence of a complex intertwining between business and family goals. This challenging relationship raises important research questions in terms of organizational structure, management styles, performance and innovation.

This research focuses on illustrating family business behavior from a technology management model approach, and tests expected family business innovation literature, including family business innovation behavior and technology management models. The semantic methodology perspective is explained, followed by findings and conclusions.

\section{Literature Review}

\subsection{Family business behavior}

Family business can be defined as a legally incorporated firm, which ownership is predominantly in the hands of a single family, and at least one family member has an executive position in the firm's top management (Gallo and Sveen, 1991). Since the firm's incorporation, family businesses exhibit distinctive behaviors, namely, a) the alignment of objectives between the owner and the executive, avoiding agency costs, as both functions merge into the same person (McConaughy et al., 1998); b) long-term project business interest approach that simultaneously protects the family interests (Mazzola, 2002); and c) internal generation of strategic resources (San Martín et al., in process).

Although there has been significant research in the subject, results are still inconclusive. Some scholars show that growth is not an organizational priority in these businesses (Zahra, 2005; De la Garza et al., 2015), prevailing family's non-economic objectives (Berrone, et al., 2012). Other studies indicate the opposite behavior: family firms seem to prioritize sales growth and net assets (Leach and Leahy, 1991), higher growth (Habbershon and Pistrui, 2002); aggresive internacionalization (Davis and Haverson, 2000); resource provisioning for development (Le Breton-Miller and Miller, 2006); and greater potential for innovation (Aronoff, 1998). Imminently, family businesses grow, either as a result of organizational structure or the family's management style (Fuentes et al., 2008).

Different factors affect family firm's innovation behavior, including a dominant role of the owner-founder, who bases her decisions on intuition, knowledge, experience and vision; Mintzberg et al. (1999) call it visionary process. Usually, the family's desire to keep control of their business represents an access barrier to venture capital investment opportunities (Gómez-Mejía, Cruz, et al., 2011). Additionally, this process creates an incompatibility between managerial competencies and ambitious innovation projects (Block et al., 2013). According to Block et al. (2013), family firms are placed into a decision dilemma: whereas more investment in significant innovations might enhance competitiveness and sustainable performance, it could also reduce family control. To answer that dilemma, family firms have shown

(1) Facultad de Economía y Negocios, Universidad Anáhuac México, Huixquilucan, México

${ }^{*}$ Corresponding author: argentina.soto@anahuac.mx 
strong preferences for incremental innovation projects, which allow them to have less economic and technical uncertainty and higher management control capacity.

On the one hand, the pursue of growth obliges family businesses to revitalize their strategy, attracting and retaining competent managers outside the family, fostering flexibility and organizational innovation, generate and preserve financial wealth and prepare a successor to lead the business (Ward, 1997). Vallejo (2003) considers that flexibility and speed in the decision-making process are core advantages in family businesses. Expectedly, proprietors would need to incorporate new shareholders and professional managers unrelated to the family, involving new governance configurations that require decreasing functional complexity and specific role definition for all stakeholders involved. However, proprietors would be reluctant to delegating control and may resort to "quasi-organic" structures. In this form of organization, control is passed to the executives, though owners maintain proprietorial prerogatives with arbitrary interventions (Goffe and Scasse, 1985).

When confronted to new challenges, organic organizations seem more useful, as their characteristics allow for: a) a change in decisionmaking from vertical to horizontal cooperation, considering that the composition of the organization consists of a maximum number of strategic top management groups and project teams (McCalman, 1996); b) departmental barriers erosion to facilitate the work of cross-functional teams and integration of specialized knowledge (Cross, 2000); c) directors' authority is granted to employees (decentralization of power and control) to participate in organizational management, proactively promoting a culture of openness and trust (Hankinson, 1999); d) higher level of informality and freedom of rules, where management grows to lead people, technology, knowledge and processes. In general, stimulus for member interaction is treated as main mechanism for creating new knowledge (Wang and Ahmed, 2003).

This research focuses on family business from an innovation perspective, which is expected to contribute to the firm's long term strategy from a technology management model approach.

\subsection{The management of technology}

Technology management can be defined as a discipline which central task is to guarantee the firm's technological competitive position within a given business strategy for a product-market relationship, involving research, product and process development management, engineering and usage of information and communication technologies (Rastogi, 1995). Its application includes a variety of considerations around the innovation phenomenon, with particular focus on the firm's impacts in terms of organizational structure and processes, stakeholders interactions (owners, employees and partners), practices, and contextual specificities (Medellin, 2010). The firm's innovation complexity can go from strategic technology acquisitions and adaptation to incremental or radical developments, and the scope of technology management includes the whole strategic planning and coordination of organizational activities (Rastogi, 1995), with the purpose of fostering technology innovation, new value-creation processes and creative commercialization models (Medellin, 2010).

In the end, technology management targets the firm's innovation. However, in order to accomplish this goal, it is important that the firm complies with certain conditions for an effective management of technology, including an appropriate framework that relates the firm's technologies, capabilities and business objectives, integrated functional teams capable of implementing innovations, technology exploitation capabilities, a technology management system, and accountable staff (Medellin, 2013). Rastogi (1995) simplifies these requirements by emphasizing the firm's ability to perceive a need for change in its technology base, as a result of the competitive environment, and subsequent skills to implement change.

At some extent, the implementation of technology management in a firm requires also innovation at the firms' management level. This fact would imply the application of new knowledge to amend the nature of the firm's organizational practices to comply with stronger technology functions (Mol and Birkinshaw, 2014). However, little research has been devoted to understanding the relationship between technology management and the organizational elements that explain it such as purpose, structure, processes and activities (Medellin, 2013). Following a design perspective, organizational structures can take either the form of social constraint (hierarchical) or social action (emergent from the bottom-up) organizations (Dougherty, 2008), which would determine the appropriate organizational path to implement technology management. Additionally, the intrafirm transfer of the employees' knowledge usually involves forms of social capital that may result in innovation performance, requiring the presence of mediation mechanisms (Maurer, Bartsch, \& Ebers, 2011).

From a family firm research perspective, which emphasizes the family's strong influence on the firm's decision-making process (De Massis, Frattini, \& Lichtenthaler, 2013; Diéguez-Soto, Manzaneque, \& Rojo-Ramírez, 2016), management innovation starts with the family owners. As a socially bounded organization, all flow of activities, integration of innovative work and emotional impulse to innovate go through the family (Dougherty, 2008). Thus, the role of mediator in the identification of useful resources, the establishment of effective socialization (business meetings), knowledge sharing (absorption) and collaboration for the transfer and circulation of ideas and knowledge goes to the family (Temel, Mention, \& Torkkeli, 2013), who becomes either a facilitator or a barrier between the firm's social capital and the innovation outcome. Table 1 below summarizes relevant family firms' behaviors as identified by some scholars (De Massis et al., 2013; Diéguez-Soto et al., 2016). As indicated, family firms would have different patterns depending on short vs long term vision. 
Table 1. Family Firms Innovation Behavior

\begin{tabular}{|c|c|c|}
\hline & Axiom/ Hyphotesis & Questions \\
\hline \multirow{16}{*}{ Short-Term Inneficiencies } & $\begin{array}{l}\text { The search for preservation of socieconomic wealth } \\
\text { affects family firms' innovation intensity } \\
\text { (Block, et al., 2013). }\end{array}$ & $\begin{array}{l}\text { Does a family manager have direct influence on the firm's inno- } \\
\text { vation strategy? } \\
\text { Besides financials, does the firm seek non-financial objectives } \\
\text { (e.g. emotional, social, etc.) in pursuing STI activities? }\end{array}$ \\
\hline & $\begin{array}{l}\text { Family firms tend to be risk averse } \\
\text { (De Massis, Frattini, et al., 2013). }\end{array}$ & $\begin{array}{l}\text { Is there risk-averse behaviour evidence in the firm's technology } \\
\text { management model? }\end{array}$ \\
\hline & \multirow{5}{*}{$\begin{array}{l}\text { Family managers are reluctant to conceding firm con- } \\
\text { trol to external partners/ investors } \\
\text { (Czarnitzki \& Kraft, 2009). }\end{array}$} & $\begin{array}{l}\text { Does the firm's technology management model include signs of } \\
\text { strong family managers' control on STI project approval? }\end{array}$ \\
\hline & & $\begin{array}{l}\text { Does the firm's technology management model limit the influence } \\
\text { of employed managers in the decision making process? }\end{array}$ \\
\hline & & Does the firm encourage or restrict STI partnerships? \\
\hline & & Does the firm loss control when partnering with external entities? \\
\hline & & Does the model prevent disruptive innovation? \\
\hline & \multicolumn{2}{|l|}{$\begin{array}{l}\text { Family firms refuse to invest in innovation if finan- } \\
\text { cial requirements exceed internal capabilities (Zahra, } \\
2005) \text {. }\end{array}$} \\
\hline & \multicolumn{2}{|l|}{$\begin{array}{l}\text { Family firms are reluctant to seek external financing } \\
\text { as this would involve loss of the firm control } \\
\text { (Munari et al., 2010). }\end{array}$} \\
\hline & \multicolumn{2}{|l|}{$\begin{array}{l}\text { Family firms tend to invest less in innovation than } \\
\text { non-family firms (Chen \& Hsu, 2009). }\end{array}$} \\
\hline & \multicolumn{2}{|l|}{$\begin{array}{l}\text { Focus is on family objectives and values (Berrone et } \\
\text { al., 2012). }\end{array}$} \\
\hline & \multicolumn{2}{|l|}{$\begin{array}{l}\text { Family firms support STI projects when innovation } \\
\text { outcomes are obtained (proven technology). (Mc- } \\
\text { Cann et al., 2001). }\end{array}$} \\
\hline & \multicolumn{2}{|l|}{$\begin{array}{l}\text { Long term outcomes motivate family firms to invest } \\
\text { in new technology } \\
\text { (Bergfeld \& Weber, 2011). }\end{array}$} \\
\hline & \multicolumn{2}{|l|}{$\begin{array}{l}\text { Social capital (quality family relationships) contrib- } \\
\text { utes to enhance innovation strategies } \\
\text { (Cassia, De Massis \& Pizzurno, 2011). }\end{array}$} \\
\hline & \multicolumn{2}{|l|}{$\begin{array}{l}\text { Family firms may rely on external knowledge for in- } \\
\text { novation as a result of external social capital(Classen } \\
\text { et al., 2012; Alberti \& Pizzurno, 2013). }\end{array}$} \\
\hline & \multicolumn{2}{|l|}{$\begin{array}{l}\text { Connections with external stakeholders increase } \\
\text { family firm performance as mental models and } \\
\text { knowledge change. }\end{array}$} \\
\hline
\end{tabular}

Source: own elaborated based on De Massis et al. (2013) and Diéguez-Soto et al. (2016)

Research literature related to technology management has focused mainly on multinational enterprises, with little interest in smaller companies (Medellin, 2013) and fully agnostic to the particularities of family firms. This paper takes these family firms' innovation characteristics and maps them into a semantic network as explained further in this paper. 


\subsubsection{Technology Management Models}

Several proposals have been put in place to model technology management at the firm's level. A technology management model (TMM) is an abstract representation of a firm's technology management system, which can be classified from different perspectives: functional, processes-oriented, based on key activities, or evaluation criteria (Medellin, 2013). There is a variety of TMM proposals in the literature (Bo and Qiuyan, 2012; Kearns, Taylor, \& Hull, 2005; Medellin, 2013), which have even been applied not only in firms but also at the sectoral level (Liao, Hull, \& Sriramachandramurthy, 2013; Luxmore and Hull, 2010).

As an instance, Kearns et al. (2005) have developed a model with six technology management facets: technology evaluation, integration, planning, implementation, training and change, which have been applied to particular sectoral cases. Medellin (2013) advocates for a model that goes beyond management elements as his TMM includes innovation capabilities while technology management involves technology strategy, organizational structure, processes and management skills, innovation capabilities refer to the firm's capacity to execute RandD, design, engineering and innovation projects, together with access to knowledge and external technologies (Medellin, 2013).

Other proposals include functional elements (optimization, enhancement, protection, inventory, assessment and surveillance), specific activities (identification, selection, acquisition, exploitation and protection) or a set of integrated considerations (technology acquisition mechanisms and sources, processes, and outcomes) (Medellin, 2013). In general, Medellin (2013) has identified TMM proposals from scholars and organizations in the United States, France, Spain, and Latin America.

In the case of Mexico, norm NMX-GT-002-IMNC-2008 has been created with the purpose of providing Mexican companies with guidance in identifying and managing technology projects. Additionally, this norm was designed to evaluate Mexican firms in terms of technology management and innovation processes. The Mexican norm was modeled after Spain's series of norms UNE 166000:2002 EX, which are consistent with the Frascati manual ${ }^{1}$. As Mexican model for technology management, NMX- GT-002-IMNC-2008 set the basis for the National Award in Technology and Innovation or $\mathrm{PNTI}^{2}$, which is offered by the federal government to recognize innovative Mexican firms. Moreover, the award is seen as a motivation and dissemination mechanism that would encourage the adoption of the TMM between Mexican firms.

The Mexican TMM involves five key technology management functions ${ }^{3}$ : surveillance, planning, habilitation, protection and implementation. Each function involves particular processes, which are listed next:
- Surveillance: benchmarking, market studies development, and technology monitoring.

- Planning: development and review of the technology plan and projects portfolio.

- Habilitation: technology acquisition, technology assimilation, technology development, technology transfer, project portfolio management, technical staff management, financial resource management, and knowledge management.

- Protect: intellectual property.

- Implementation: process, products, marketing and organizational innovations.

Though the model provides definitions for each item, it does not offer any details on how companies should implement the TMM, allowing for excessive flexibility and model interpretation. Mexican firms report their TMM to the PNTI and the winners' documents are made public in the PNTI website. Critics indicate that these documents report activities, not an actual model, without explaining how the firms' key technology management processes develop or particular objectives that support these processes (Medellin, 2013). Additionally, Medellin (2013) finds that most PNTI winners lack process consistency, systematization and efficacy, as well as an implementation methodology to constitute a technology management system.

In spite of criticism about the Mexican TMM, their PNTI reports provide valuable transversal information on the firms' technology activities, innovation values and organizational flows. Research Methodoly

To achieve our research objectives, This paper confronts what the literature claims about innovation in family firms to the web of textual meaning contained in Coprobamex' TMM document.

Coprobamex (http://www.coprobamex.com) is a Mexican family business incorporated in 1990 that specializes in the sugar industry. Founded by the the Bojorquez brothers, the company has evolved to create value-added sugar-based products, such as Sucraliq, which is liquid sugar, highly used in the food industry. Coprobamex is one the 2009 PNTI winners and the company's report on what they see as TMM offers details on how this family firm deals with innovation, disclosing organizational decision making flows, knowledge partnerships and company values. This information has helped us to determine literature consistency with the firm's innovation and technology management behavior. Taken as case study, Coprobamex' report has been used to test our analytical framework on family businesses' TMM.

On the one hand, based on the literature review summarized in table 1 above, we have come up with 15 meaningful interpretations of what characterizes family firms. These interpretations (features) are listed in table 2 below.

(1) http://www.oecd.org/sti/inno/Frascati-Manual.htm

(2) http://pnt.org.mx

(3) http://pnt.org.mx/modelo-nacional 
Table 2. Family firms innovation behavior characteristiques

1. Social Recognition

2. Economic Wealth

3. Innovation thinking

4. Family member direct influence

5. Risk-averse behavior

6. Employees limitations in the decision making

7. Encouragement of STI partnership

8. Fear to loss control to external partners

9. Model prevents disruptive innovation

10. Refuse external finance

11. Less investment in innovation

12. STI supported if clear outcomes

13. Family relations contribute to innovation

14. Reliance on external knowledge

15. External connection increases firm performance

Source: authors' extraction based on De Massis et al., (2013) and Diéguez-Soto et al., (2016)

Additionally, we have identified 8 key players related to specific functions and power relations according to the company's TMM. These actors are presented in table 3 below.

\section{Table 3. Coprobamex key players related to TMM}

1. Family-control (family members)

2. Investors

3. New-products

4. Outcome-oriented (objectives)

5. Partners (external)

6. Society

7. Stakeholders (the firm)

8. Team (employees and owners)

Source: authors' extraction

Coprobamex TMM report is divided in 8 sections, including: 1) mission; 2) vision; 3 ) model introduction, and the model's five key functions; 4) surveillance; 5) planning; 6) habilitation; 7) protection; and 8) implementation, which are the main object of analysis. We assessed key concepts in each section and collected their meaning to map them into one of aforementioned interpretations. For example, if Coprobamex document indicates in its implementation section that the CEO of the company has a direct monitoring function on how each technology project is executed in order to guarantee that it complies with the firm's priorities, this is a clear indicator of strong family control on the business operations. Hence, interpretation "Family member direct influence" and key player "Family-control" become semantically related to the function "implementation". We mapped each semantic finding for "interpretations" to the corresponding "section" whenever the text indicated a new meaning. In parallel, we mapped the "key player" involved in the interpretation to the corresponding "section".

Using network analysis software (NodeXL), we graphically compared the 8 "sections" to semantic mappings for each of the "interpretations" (features) taken from the text. We also mapped "sections" to "key players". The results are available in the figures below.

Figure 1. Interpretation perspective map

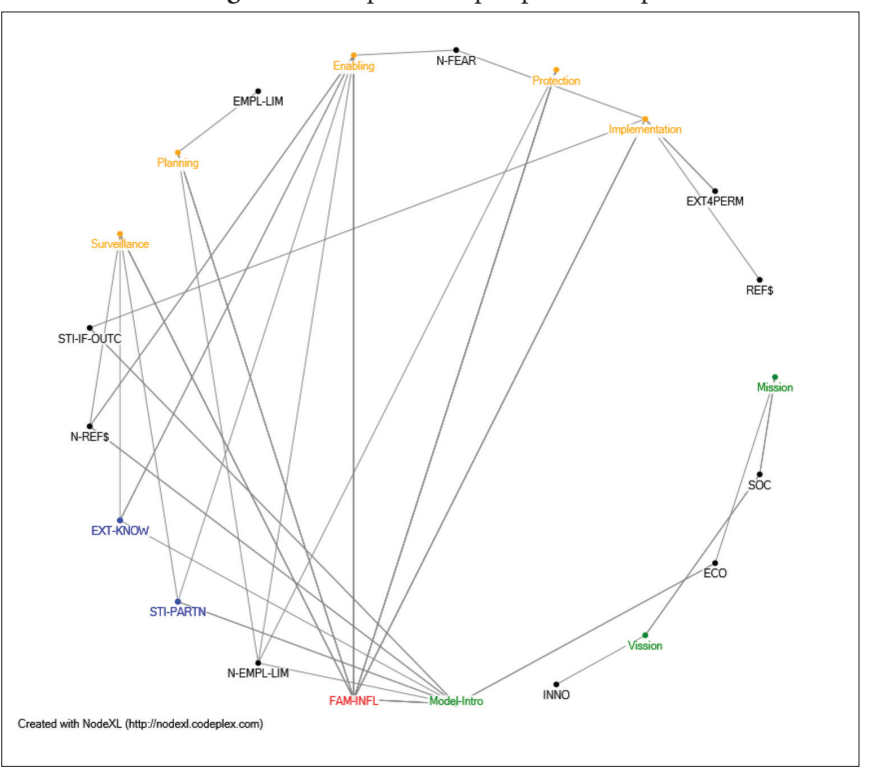

( $\mathrm{N}$ - denotes negative relation)

From the "interpretations" perspective, Figure 1 shows "Family member direct influence" (FAM-INFL) as the main node in the network, which has connections to all sections in the TMM. "Encouragement of STI partnership" (STI-PARTN) and "Reliance on external knowledge" (EXT-KNOW) have both links to the TMM surveillance and enabling functions. Interestingly, "Employees limitations in the decision making" (EMPL-LIM and N-EMPL-LIM) has a positive and a negative relation to planning. "Employees limitations in the decision making" has also negative links to the enabling and protection functions and "Fear to loss control to external partners" (N-FEAR) is negatively associated to enabling and implementation. Additionally, while "Refuse external finance" (REF\$ and N-REF\$) is negatively 
related to enabling, it has positive participation in the implementation function. "External connection increases firm performance" (EXT4PERM) has also a positive connection to implementation. Finally, "STI supported if clear outcomes" (STI-IF-OUTC) is a concept mentioned in the implementation function and the introduction of the model.

Figure 2. Sections-Key Players perspective map

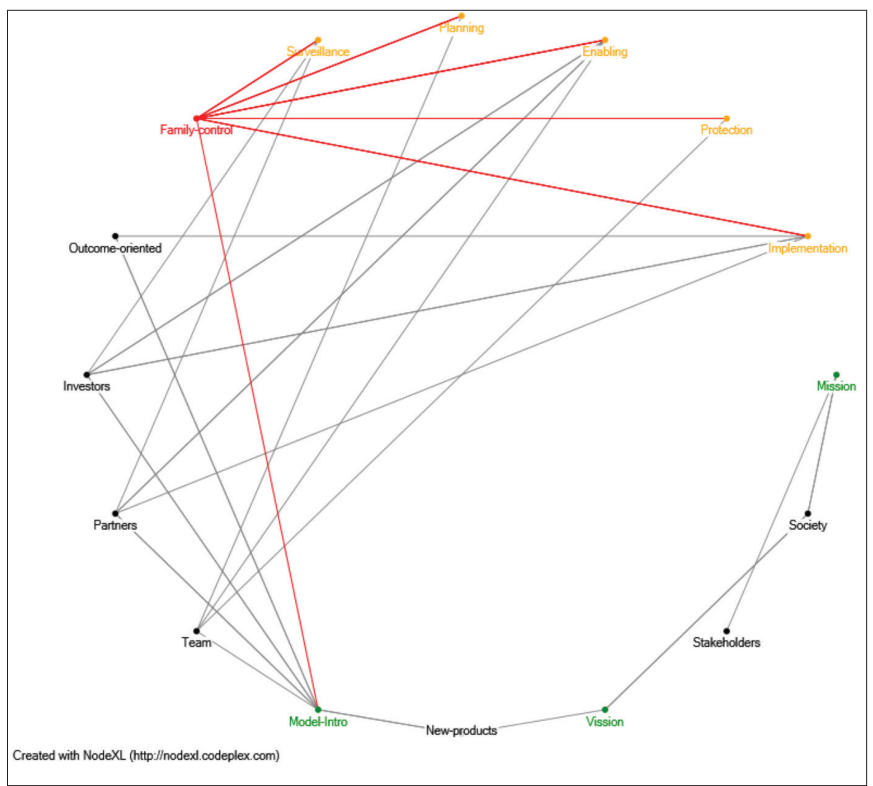

Similarly, Figure 2 puts together TMM sections and actors. Again, Family-control has connections to all the TMM functions. Both Investors and Partners relate to the surveillance, enabling and implementation functions. Team participation is present in the planning, enabling and protection functions. In the implementation and model introduction, the semantics indicates the importance of outcomeoriented meaning. This outcome is consistent with the "interpretations" perspective.

\section{Results}

From the network analysis shown above, it is possible to confirm some of the innovation features in a family firm behavior, as tested in the case of Coprobamex. Some short-term inefficiencies detected in the literature can be corroborated. The case under analysis confirms strong direct influence and control from the family, clearly signaled in both network analyses, endorsing findings in the literature about the family managers unwillingness to cede control (Diéguez-Soto et al., 2016). Particular TMM functions such as surveillance and enabling welcome STI partnerships and external knowledge, which is an indicator of the firm reliance on partners to identify new technologies and make their development a reality, as indicated by Alberti and Pizzurno (2013), De Massis et al. (2013) and Classen et al. (2012). Though employees do participate in the firm's planning process, their involvement seems limited, indicating strong controls as well (Czarnitzki \& Kraft, 2009; Diéguez-Soto et al., 2016). However, the firm's staff has more participation in finding resources to develop the new product (enabling) and intellectual property protection, which is a fact that doesn't contradict the literature review as family control of the decision making process remains.

On the other hand, this case indicates that the firm is not concerned about losing control in some parts of the family business, as they are open to external resources and investment (enabling and implementation) within some limits (e.g. no external influence in the planning and protection functions), suggesting contextual boundaries to statements made by Munari et al. (2010). Concerning long term efficiencies, the firm's TMM confirms that STI would be supported if there are clear outcomes demonstrated in previous technology development phases (McCann et al., 2001), usually by partnering with RandD institutions. In general, external connections aim at increasing firm performance, confirming family firms' behavior as reported by scholars though bounded by Coprobamex' contextual elements.

\section{Conclusions}

Interweaving business and family goals would represent one of the main causes for underperformance. Family business control is established as a key factor for survival (Cisneros and Hernández, 2011); hence, the growing research interest in the subject.

In general, family businesses focus on formal control mechanisms, in opposition to organic or quasi-organic organizations. This is the natural result of family concerns to maintain control of the company and reduce the uncertainty caused by structural growth or the so-called institutional overlap. Usage risks are also recognized when such mechanisms threaten the firm's innovation capacity or their flexibility to face innovation challenges. Typical factors that hinder technology innovation include top management isolation, unreceptiveness to new ideas, excessive controls, and inappropriate incentives for innovators (Rastogi, 1995). Family firms tend to adopt these organizational inhibitors, as demonstrated in the case of Coprobamex.

In particular, it is instrumental that the organizational structure considers the role of the technology manager, who should be a knowledgeable and experienced professional in the field, and can make the linkage between enterprise strategy and technology as long as this figure is present in the firm's management board (Medellin, 2013).

The use of the TMM from an semantic network perspective has allowed for a family firm innovation behavior characterization. Though the model may have several limitations for real implementation, since it has been written by the family firm itself, the information provided becomes valuable to understand the firm's values and thinking about innovation.

For future research, we suggest further characterization of more family businesses' innovation behavior in developing countries, which would allow for targeted enterprise development policies, especifically family-owned SMEs. Additionally, we believe that the methodological framework presented in this paper is an original contribution to research that can be extended to a larger set of business types, gaining external validity if a relevant number of companies is considered. 


\section{References}

Aghion, P., and Howit, P. (1992). A model of growth through creative destruction. Econometrica, 60, 323-351. doi: http://dx.doi.org/10.3386/w3223.

Alberti, F. G. and Pizzurno, E. (2013). Technology, innovation and performance in family firms. International Journal of Entrepreneurship and Innovation Management, 17(1/2/3), 142-161. doi: http://dx.doi.org/10.1504/ijeim.2013.055253.

Aronoff, C. (1998). Megatrends in family business. Family Business Review, 11(3), 181-186. doi: http://dx.doi.org/10.1111/j.1741-6248.1998.00181.x.

Bergfeld, M.-M. H., and Weber, F.-M. (2011). Dynasties of innovation: Highly performing German family firms and the owners' role for innovation. International Journal of Entrepreneurship and Innovation Management, 13(1), 80-94. doi: http://dx. doi.org/10.1504/ijeim.2011.038449.

Berrone, P., Cruz, C., Gómez-Mejía, L. (2012). Socioemotional wealth in family firms: theoretical dimensions, assessment approaches, and agenda for future research. Family Business Review, 25(3), 258-279. doi: http://dx.doi.org/10.1177/0894486511435355.

Block, J., Miller, D., Jaskiewicz, P., and Spiegel, F. (2013). Economic and technological importance of innovations in large family and founder firms an analysis of patent data. Family Business Review, 26(2), 180-199. doi: http://dx.doi.org/10.1177/0894486513477454.

Bo, Z., and Qiuyan, T. (2012). Research of SMEs' technology innovation model from multiple perspectives. Chinese Management Studies, 6(1), 124-136. doi: http://dx.doi.org/10.1108/17506141211213825.

Cassia, L., De Massis, A., and Pizzurno, E. (2011). An exploratory investigation on NPD in small family businesses from Northern Italy. International Journal of Business, Management and Social Sciences, 2(2), 1-14.

Chen, H. L., and Hsu, W. T. (2009). Family ownership, board independence, and R\&D investment. Family Business Review, 22, 347362. doi: http://dx.doi.org/10.1177/0894486509341062.

Cisneros, L., and Hernández, A. (2011). Control en la empresa familiar. AD-minister, 18, 49-76.

Classen, N., Van Gils, A., Bammens, Y., and Carree, M. (2012). Accessing resources from innovation partners: The search breadth of family SMEs. Journal of Small Business Management, 50, 191-215. doi: http://dx.doi.org/10.1111/j.1540-627x.2012.00350.x.

Cross, R. (2000). Looking before you leap: assessing the jump to teams in knowledge-based work. Business Horizons, 43(5), 29-36. doi: http://dx.doi.org/10.1016/s0007-6813(00)80006-3.
Czarnitzki, D., and Kraft, K. (2009). Capital control, debt financing and innovative activity. Journal of Economic Behavior \& Organization, 71, 372-383. doi: http://dx.doi.org/10.2139/ssrn.610243.

Davis, P., Harverson, P. (2000). Internationalization and organizational growth: the impact of internet usage and technology involvement among entrepreneur-led family business. Family Business Review, 13(2), 107-120. doi: http://dx.doi.org/10.1111/j.1741-6248.2000.00107.x.

De la Garza, M.I., Díaz, J.G., Jiménez, K.P., Medina, J.M. (2015). El crecimiento en la empresa familiar, factor de continuidad. Un estudio de negocios de primera, segunda y tercera generación en el estado de Tamaulipas, México. En Mipymes, empresas familiares y organizaciones emergentes. Experiencias en México, Guatemala y España. 189-203.

De Massis, A., Frattini, F., and Lichtenthaler, U. (2013). Research on technological innovation in family firms: Present debates and future directions. Family Business Review, 26(1), 10-31. doi: http://dx.doi.org/10.1177/0894486512466258.

Diéguez-Soto, J., Manzaneque, M., and Rojo-Ramírez, A. A. (2016). Technological Innovation Inputs, Outputs, and Performance: The Moderating Role of Family Involvement in Management. Family Business Review, 29(3), 327-346. doi: http://dx.doi.org/10.1177/0894486516646917.

Dougherty, D. (2008). Bridging Social Constraint and Social Action to Design Organizations for Innovation. Organization Studies, 29(3), 415-434. doi: http://dx.doi.org/10.1177/0170840607088021.

Durán, J., San Martín, J. M. (2016). Evolución de la planeación estratégica en la empresa familiar en México. En Panorama de la Administración en México, Duhamel, F. y Gutiérrez, I. Edit. UDLAP. Puebla, México.

Fuentes, G., Hernández, M., Vallejo, M. (2008). Razones para crecer en la empresa familiar: un análisis comparativo. Investigaciones Europeas de Dirección y Economía de la Empresa, 14(3), 15-34. doi: http://dx.doi.org/10.1016/s1135-2523(12)60064-1.

Gallo, M. A., \& Sveen, J. (1991). Internationalizing the family business: Facilitating and restraining factors. Family Business Review, 4(2), 181-190. doi: http://dx.doi.org/10.1111/j.1741-6248.1991.00181.x.

Goffe, R. and Scasse, R. (1985). Proprietorial control in family firms. Some functions of "quasi-organic" management systems. Journal of Management Studies, 22(1), 53-68. doi: http://dx.doi.org/10.1111/j.1467-6486.1985.tb00242.x.

Gómez-Mejía, L., Cruz, C., Berrone, P. and De Castro J. (2011). The bind that ties: socioemotional wealth preservation in family firms. Academy of Managment Annals, 5, 653-707. doi: http://dx.doi.org/10.1080/19416520.2011.593320. 
Habbershon, T., Pistrui, J. (2002). Entrerprising families' domain: family-influenced ownership groups in poursuit of transgenerational wealth. Family Business Review, 15(3), 223-238. doi: http://dx.doi.org/10.1111/j.1741-6248.2002.00223.x.

Hankinson, P. (1999). An empirical study wich compares the organisational structures of companies managing the world's top 100 brands with those managing outsider brands. Journal of Product and Brand Management, 8(5), 402-4014. doi: http://dx.doi.org/10.1108/10610429910296000.

Kearns, M. B., Taylor, J. B., and Hull, C. E. (2005). The six facets model: technology management in the effective implementation of change. International Journal of Innovation and Technology Management, 2(1), 77. doi: http://dx.doi.org/10.1142/s0219877005000381.

Le Breton-Miller, I., Miller, D. (2006). Why do some family business outcompete?: Governance, long-term orientations, and sustainability capability. Entrepreneurship Theory and Practice, 30(6), 731-746. doi: http://dx.doi.org/10.1111/j.1540-6520.2006.00147.x.

Leach, D., Leahy, J. (1991). Ownership structures, control and the performance of large British companies. Economic Journal, 101, 1433. doi: http://dx.doi.org/10.2307/2234893.

Liao, A., Hull, C. E., and Sriramachandramurthy, R. (2013). The six facets model of technology management : a study in the digital business industry. International journal of innovation and technology management, 10(4), 1-24. doi: http://dx.doi.org/10.1142/s0219877013500193.

Luxmore, S. R., and Hull, C. E. (2010). Externalities and the six facets model of technology management: genetically modified organisms in agribusiness. International journal of innovation and technology management, 7(1), 19-36. doi: http://dx.doi.org/10.1142/s0219877010001799.

Mazzola, P. (2002). The role of going public in family businesses' longlasting growth: a study of italian IPOs. Family Business Review, 15(2), 133-148. doi: http://dx.doi.org/10.1111/j.1741-6248.2002.00133.x.

McCalman, J. (1996). Lateral hierarchy: the case of cross-cultural management teams. European Management, 14(5), 509-517. doi: http://dx.doi.org/10.1016/0263-2373(96)00045-x.

McCann, J. E., Leon Guerrero, A. Y., and Haley, J. D., Jr. (2001). Strategic goals and practices of innovative family businesses. Journal of Small Business Management, 39(1), 50-59. doi: http://dx.doi.org/10.1111/0447-2778.00005.
McConaughy, D., Walker, M., Henderson, G., Mishra, C. (1998). Founding family controlled firms: efficiency and value. Review of Financial Economics, 7, 1-19. doi: http://dx.doi.org/10.1016/s1058-3300(99)80142-6.

Medellin, E. (2010). Gestión tecnológica en empresas innovadoras mexicanas. RAI - Revista de Administração e Inovação, 7(3), 21. doi: http://dx.doi.org/10.5585/rai.2010684.

Medellin, E. (2013). Construir la innovación: Fese, Fundación Educación Superior-Empresa.

Mintzberg, H., Ahlstrand, B., Lampel, J. (1999). Safari en pays stratégie, l'exploration des grands courants de la pensée stratégique. Paris: Village Mondial.

Mol, M. J., and Birkinshaw, J. (2014). The Role of External Involvement in the Creation of Management Innovations. Organization Studies, 35(9), 1287-1312. doi: http://dx.doi.org/10.1177/0170840614539313.

Munari, F., Oriani, R., and Sobrero, M. (2010). The effects of owner identity and external governance systems on R\&D investments: A study of Western European firms. Research Policy, 39(9), 1093-1104. doi: http://dx.doi.org/10.1016/j.respol.2010.05.004.

Rastogi, P. N. (1995). Management of technology and innovation: competing through technological excellence: Sage Publications. doi: http://dx.doi.org/10.4135/9788132108276.n10.

Temel, S., Mention, A. L., \& Torkkeli, M. (2013). The impact of cooperation on firms' innovation propensity in emerging economies. Journal of Technology Management \& Innovation, 8(1), 54-64. doi: http:// dx.doi.org/10.4067/s0718-27242013000100006.

Vallejo, M. (2003). La cultura de la empresa familiar como ventaja competitiva: una aplicación al sector de concesionarios de automoción. Tesis doctoral no publicada. Departamento de Administración de Empresas, Contabilidad y Sociología, Universidad de Jaén.

Wang, C. \& Ahmed, P. (2003). Structure and structural dimensions for knowledge-based organizations. Measuring Business Excellence, 7(1), 51-62. doi: http://dx.doi.org/10.1108/13683040310466726.

Ward, J. (1997). Growing the family business: special challenges and best practices. Family Business Review, 10, 323-337. doi: http://dx.doi.org/10.1111/j.1741-6248.1997.00323.x.

Zahra, S. (2005). Entrepreneurial risk taking in family firms. Family Business Review, 18(1), 23-40. doi: http://dx.doi.org/10.1111/j.17416248.2007.00082.x. 
